\title{
Kugelzellen in larval anuran epidermis: an ultrastructural study on tadpoles of Pelobates cultripes (Pelobatidae) and Phyllobates bicolor (Dendrobatidae)
}

\author{
Giovanni Delfino ${ }^{1}$, Sara Quagliata ${ }^{1}$, Filippo Giachi ${ }^{1}$, Cecilia Malentacchi ${ }^{2}$ \\ ${ }^{1}$ Dipartimento di Biologia Animale e Genetica dell'Università di Firenze, via Romana 17, 50125 Firenze, Italy, \\ delfino@dbag.unifi.it \\ ${ }^{2}$ Dipartimento di Fisiopatologia clinica dell'Università di Firenze, viale Pieraccini 6, 50139 Firenze, Italy
}

Key words: anuran larvae

\begin{abstract}
Prior to hind limb development, tadpoles of the western spadefoot frog Pelobates cultripes (Pelobatidae) and dart-arrow frog Phyllobates bicolor (Dendrobatidae) possess large clear cells in the basal layer of the epidermis. These cells closely resemble Kugelzellen (KZn) of larval clawed frog, Xenopus laevis (Pipidae) and share ultrastructural traits with Leydig cells (LCs) of Caudata and Caecilia. In both species, KZn possess a transparent cytoplasm and a remarkable peripheral cytoskeleton of tonofilaments: in the arrow frog tonofilaments form bands parallel to the cell surface, in the spadefoot frog thin bundles, arranged in a three-dimensional network. KZn combine turgor (resulting from the hydrated cytoplasm) with stiffness (from peripheral cytoskeleton), thus providing structural stability to the larval epidermis.
\end{abstract}

\section{Contents}

Introduction 213

Material and methods 214

Results

214

Discussion

217

References

218

\section{Introduction}

Large cells characterized by translucent cytoloplasm and involved in secretory or mechanical roles have been described in the epidermis of amphibian larvae (Fox, 1988). Gregarious bufoniid tadpoles possess giant cells (Riesenzellen, RZn) with basal-apically arranged organelles and secretory granules resembling the products of serous glands in adult toad skin (Delfino, 1991; Delfino et al., 1995a, b). Giant cells synthesize alarm substances that, once released into the environ (Fox, 1988), trigger fright reaction in tadpoles (Pfeiffer, 1974).
Larval urodeles (Kelly, 1966; Fährmann, 1971a, b; Greven, 1980; Fox, 1988) as well as caecilians (Fox, 1986a, b; Breckenridge et al., 1987; Fox,1988) possess spheroid-ellipsoidal cells (Leydig cells, LCs) that exhibit a complex, peripheral cytoskeleton (Langerhans net) of tonofilaments (Fährmann, 1971a, b; Greven, 1980; Rosenberg et al., 1982; Kantorek and Clemen, 1990). LC cytoplasm exhibits a central-peripheral polarization: the inner, perinuclear region (Hofcytoplasma) contains biosynthesis organelles, the outer region granules of various density. These granules may be discharged following LC rupture (Jarial, 1989) or released through merocrine processes (Quagliata et al., 2006).

Similar epidermal cells have been described in tadpoles of the South African clawed frog Xenopus laevis and referred to as Kugelzellen (KZn or ball cells), on account of their spheroid shape (Fröhlich et al., 1977). KZn have also been described as clear cells (Fox, 1988) or "vacuoles" (Seki et al., 1989) due to their remarkably transparent cytoplasm. KZn do not exhibit any ultrastructural patterns of secretory activity, but possess thick bundles of tonofilaments and a dense layer of peripheral cytoplasm (Fröhlich et al., 1977, Delfino and Malentacchi, 2006; Quagliata et al., 2006). KZn perform a mechanical function (Fröhlich et al., 1977) before undergoing degeneration during metamorphosis.

On account of the remarkable subcellular features outlined above, the present light and transmission electron microscope (LM and TEM) study investigates the larval epidermis of the western spadefoot frog Pelobates cultripes (Cuvier, 1829) and dart-arrow frog Phyllobates bicolor Duméril and Bibron, 1841, representative of distant branches: families Pelobatidae [97] and Dendrobatidae [462] of the 
anuran phylogenetic tree (Frost et al., 2006). Although these frogs have been investigated in previous studies on epidermal specialized cell lines (Delfino and Malentacchi, 2006; Quagliata et al., 2006), this is the first comparative report which analyses $\mathrm{KZn}$ in their tadpoles.

\section{Material and methods}

We analysed limbless tadpoles in the ontogenetic range 23-27, marked by development of operculum and la- bial teeth (Gosner, 1960). Epidermis maintains a stable structure in these stages, until cutaneous glands develop during toe morphogenesis (Delfino et al., 1991). Tadpoles of Pelobates cultripes - six specimens - and Phyllobates bicolor - eight specimens - were collected near Ciudad Real (Spain) and Medelin (Colombia), respectively, and sacrificed with $0.1 \%$ chlorobutanol. Skin strips, $9 \mathrm{~mm}^{2}$, were fixed in the Karnovsky (1965) solution, postfixed in $1 \% \mathrm{OsO}_{4}$ (both in cacodylate buffer) and embedded in Epon 812. Semi-thin sections of $1.5 \mu \mathrm{m}$ thickness (for the LM) were stained with buffered (1\%, borax) toluidine blue, ultrathin sections
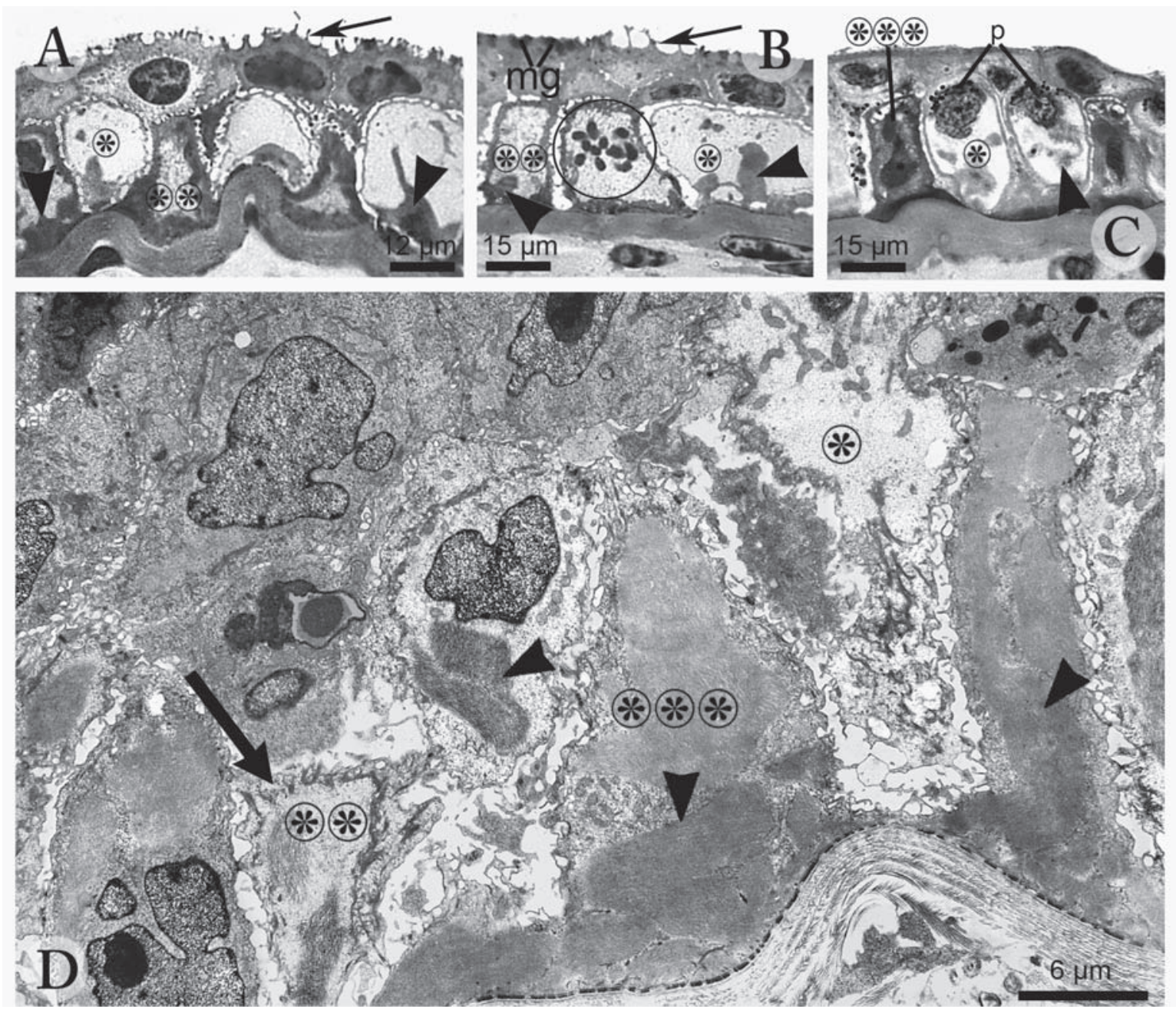

Fig. 1. Epidermis structure in limbless tadpoles of Phyllobates bicolor (a-b, LM micrographs) and Pelobates cultripes (c, LM micrograph; d, TEM micrograph). A. KZn and pavement cells varying in cytoplasm density. B. Mitotic pattern (encircled) in KZ and mucous granules (mg) in pavement cell. C. KZn with different cytoplasm densities and melanin granules (p). D. KZn vary considerably in both cytoplasm density and filament content. $(*)(*)(*) \diamond(*)=$ decreasing cytoplasm density, small arrows in a and b point to microridges, arrowheads in a-d to basal tonofilament patches, large arrow in $\mathrm{d}$ to peripheral cytoskeleton. 

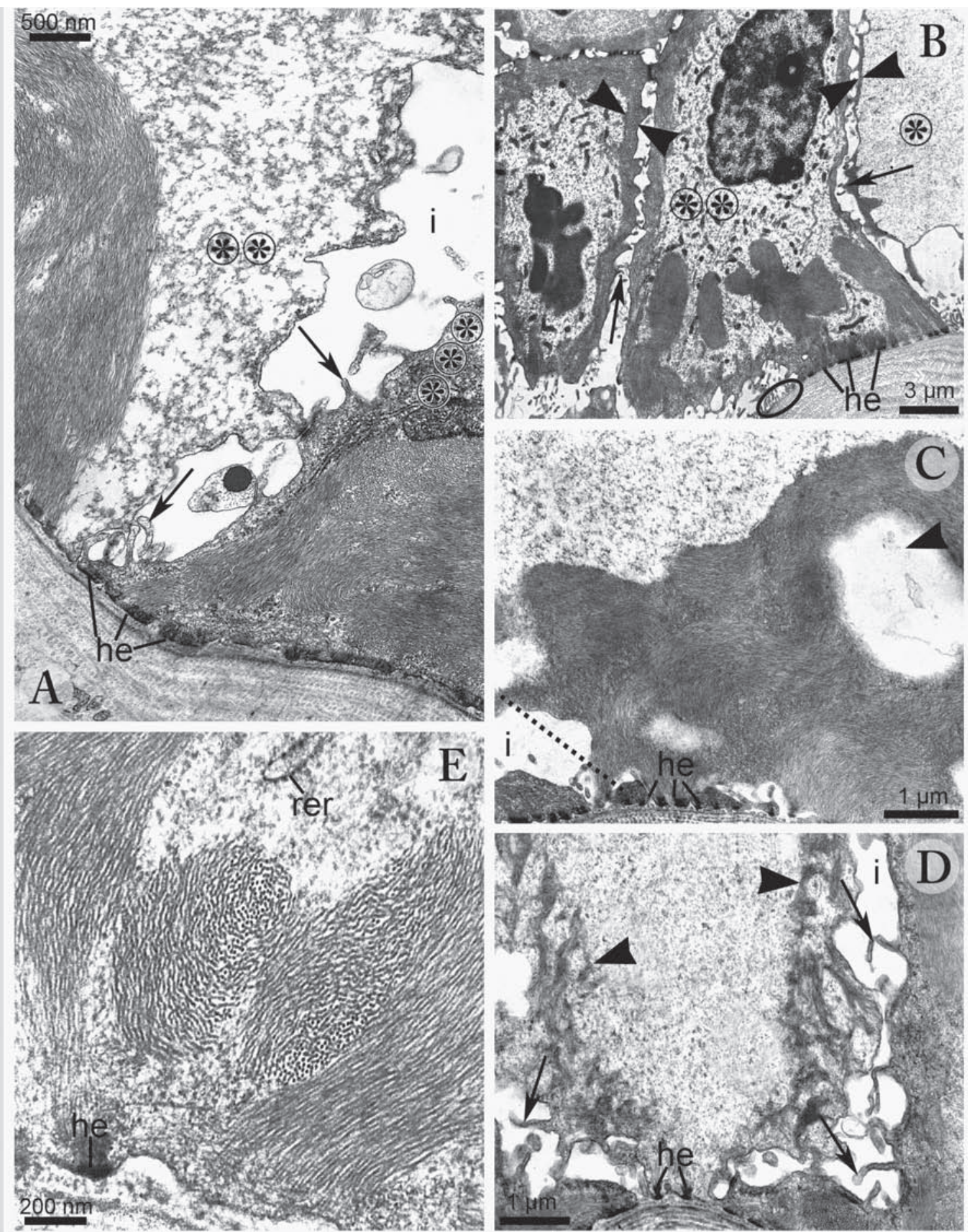

Fig. 2. Basal tonofilament bundles and hemidesmosomes in KZn of Pelobates cultripes (a, d) and Phyllobates bicolor (b, c, e). A. Both submature (*)(*) and immature $(*)(*)(*)$ KZn exhibit basal bundles. B. Two submature KZn (*)(*) and one mature KZ (*) with thick and thin cytoplasm 'cortices', respectively (opposite arrowheads); ellipse encircles a hemidesmosome-free area at the dermal-epidermal interface. C. The light area (arrowhead) is an interstitial space in a semi-tangential cell section, as suggested by the dotted line. D. In this mature KZ, tonofilaments form a micro-trabeculation (arrowheads). E. Tonofilaments converging towards the dermal side. Arrows point to thin cytoplasm processes, he $=$ hemidesmosomes, $\mathrm{i}=$ interstice, rer $=$ rough endoplasmic reticulum. 


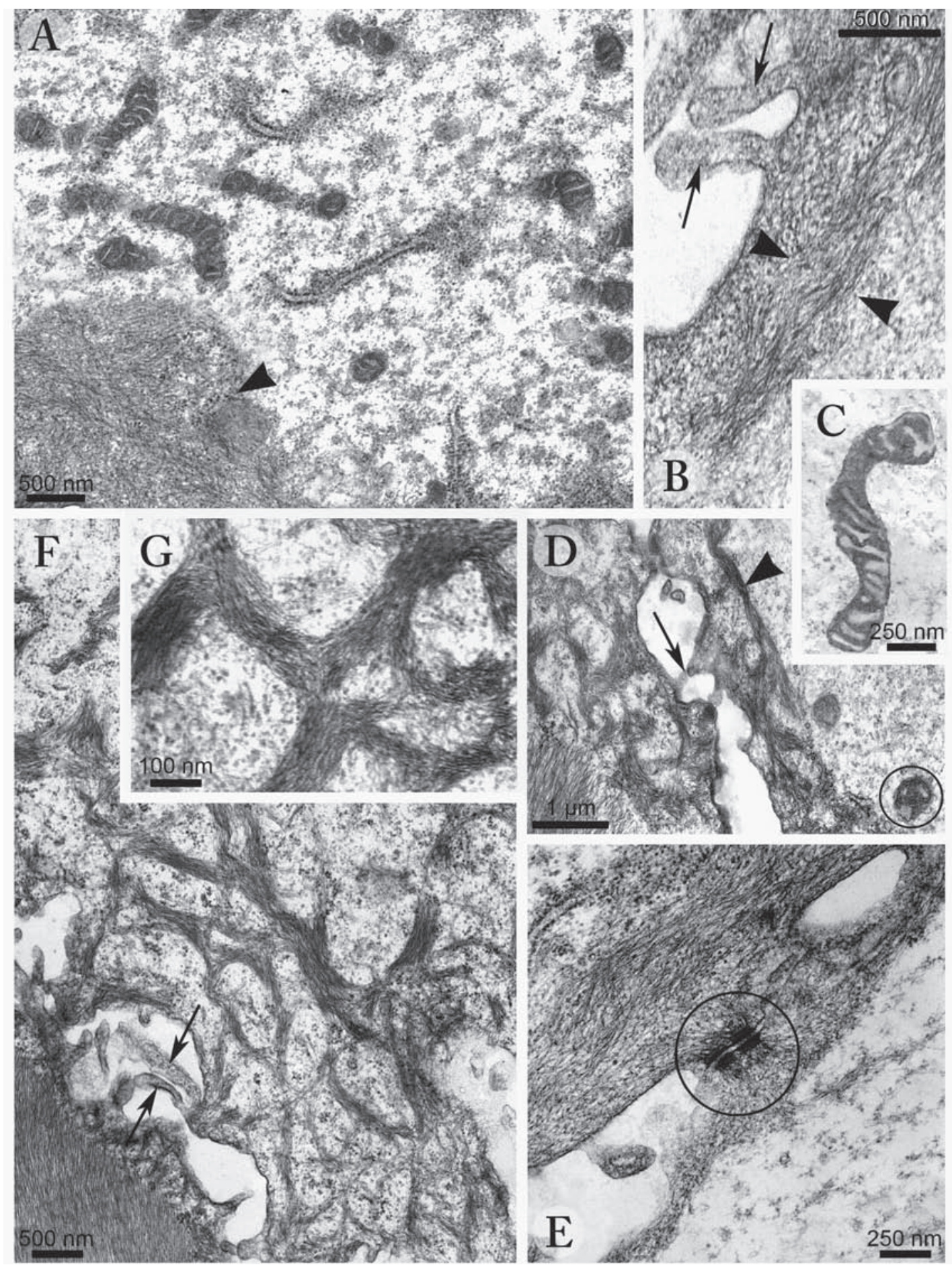

Fig. 3. Representative organelles and lateral portions of KZn. Pelobates cultripes (d, f, g) and Phyllobates bicolor (a, b, c, e). A. Cisterns of rough endoplasmic reticulum and mitochondria with dense matrix; arrowhead points to a tonofilament patch. B. Slender processes (arrows) from KZn and peripheral tonofilaments with a regular course (opposite arrowheads). C. Mitochondrion with dilated cristae. D. Micro-trabeculation (arrowhead) and spheroid mitochondrion with dilated cristae (encircled); arrow points to slender cytoplasm process. E. Desmosomes (encircled) and contiguous cell cortices. F. Irregular, micro-trabeculation network; arrows point to slender cytoplasm processes. G. Detail of micro-trabeculation. 

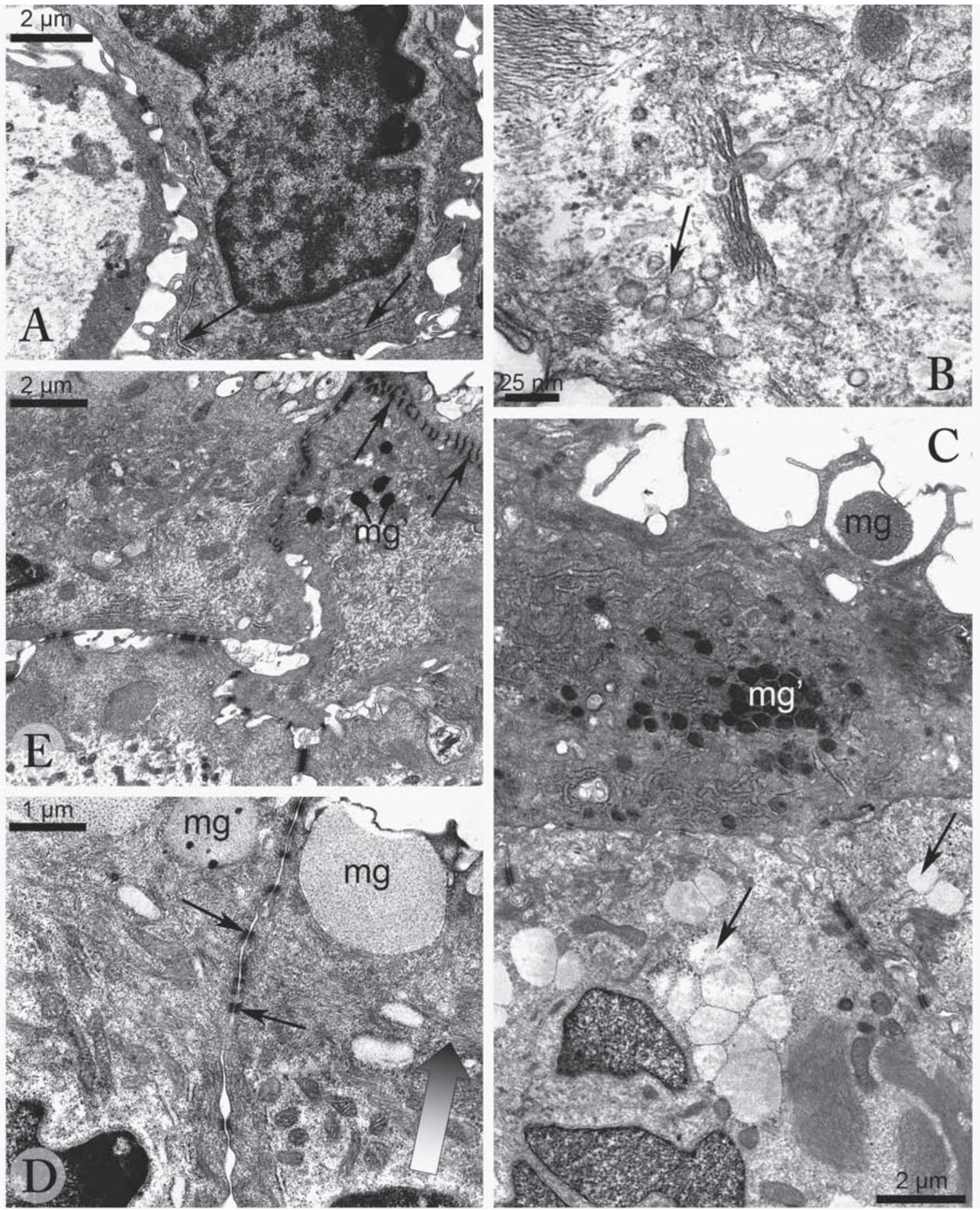

Fig. 4. Biosynthesis machinery in KZn (a, Phyllobates bicolor, b and c, Pelobates cultripes) and secretory activity in pavement cells (c, Pelobates cultripes, d and e, Phyllobates bicolor). A. Immature KZ with slender rough reticulum cisterns (arrows). B. Golgi stack releasing minute vesicles (arrow). C. Pavement cell storing small dense granules (mg') and releasing a larger granule (mg), contiguous to immature KZn holding vesicle clusters (arrows). D. Serial desmosomes (arrows) and large granules (mg) near the body surface. The large, grey-gradient arrow shows a gradual increase in cytoplasm density. E. Small dense granules (mg') and serial desmosomes (arrows). 
with a hydroalcoholic saturated solution $(25 \mathrm{mg} / \mathrm{ml})$ of uranyl acetate followed by alkaline lead citrate $(2 \mathrm{mg}$ / $\mathrm{ml})$. Ultrathin sections were observed $(80 \mathrm{KV})$ with a Siemens 101 TEM.

\section{Results}

Since epidermis in Pelobates cultripes and Phyllobates bicolor tadpoles exhibits similar structural and ultrastructural traits, a common description has been given, unless distinctive features were observed.

LM analysis: Larval epidermis is a bilayered epithelium with inner (basal) and outer (pavement) cells that shows specific morphological traits (Fig. 1A-C). Inner cells have been ascribed to the basal layer since they contact the basement membrane (dermal-epidermal junction), regardless of their derivation from the undifferentiated epidermis cells. Basal cells rest on a relatively thick dense dermis, and are large and tall prismatic to spheroid-ellipsoidal in shape. Pavement cells are smaller and roughly cuboidal or short prismatic in shape. On the dermal side of the basal cells, tonofilaments form dense patch-bands (Fig. 1A-C) in a cytoplasm background that ranges from opaque in prismatic cells to translucent in spheroid-ellipsoidal cells. These clear cells have been regarded as mature KZn, the main target of our research. In P. bicolor they possess an obvious peripheral layer of opaque cytoplasm (cortex, Fig. 1A, B), which is thinner in translucent KZn than KZn with a relatively dense cytoplasm, sometimes engaged in mitotic processes (Fig. 1B). Cytoplasm density is also variable in pavement cells (Fig. 1) which contain mucous granules (Fig. 1B) near their microridged free surface (Fig. 1A, B).

TEM analysis: oblique sections and/or partially overlapping of contiguous cells may give the appareance of a multi-layered epidermis (Fig. 1D). A somewhat range of cytoplasm density and tonofilament content is obvious in $\mathrm{KZn}$, suggesting a maturational evolution: as a rule, the denser the cytoplasm the larger the amounts of filaments, accumulating in the infranuclear cytoplasm. Beside basal tonofilament accumulations, translucent $\mathrm{KZn}$ contain a distinctive peripheral cytoskeleton (Fig. 1D). All KZn contact the dermal-epidermal junction (Fig. 2A-E), confirming that they belong to the basal cell layer. On the dermal side, the tonofilament bundles arch upwards, approaching to the plasma membrane (Fig. 2E) and contributing to the hemidesmosomes (Fig. 2A-E). These junctions are not found only where KZn reach the epidermal-dermal junction with thin processes (Fig. 2B). Relationships between contiguous KZn are relatively loose on the dermal side, resulting in wide interstices (Fig. 2A, D). In P. bicolor KZn, the tonofilaments in the infanuclear cytoplasm form peripheral leaf-like patches (Figs. 2B and 3A) and bands roughly parallel to the cell surface (Fig. 2B). The tonofilament patches contour exiguous compartments of the interstices, contained in invaginations of KZ surface (Fig. 2C). In P. cultripes KZn the peripheral cytoskeleton of the infranuclear cytoplasm is less compact, forming a reticular framework (Fig. 2D).

The lateral surfaces of KZn emanate thin processes resembling irregular microvilli (Figs. 2A, B, D and $3 \mathrm{~B}, \mathrm{D}, \mathrm{F})$ as well as larger processes joined by spot desmosomes (maculae adherentes, Fig. 3E). The cytoskeleton retains differential features in the two species: tonofilament bands roughly parallel to the lateral cell surface in P. bicolor (Fig. 3B, E), but irregular micro-trabeculation networks in P. cultripes, (Fig. 3D, F, G). Submature KZn contain slender rough endoplasmic reticulum (rer) cisterns (Figs. 2E and 3A), as well as small mitochondria with dense matrix (Fig. 3A) and dilated cristae (Fig. 3C, D). In P. bicolor, an obvious cell cortex starts to appear in immature KZn (Fig. 4A), assumes its typical appearances as a dense 1-1.5 $\mu \mathrm{m}$ thick cytoplasm layer in intermediate maturational stages (Fig. 2B), and eventually thins out in translucent KZn (Figs. 2B and 3E). High nucleo-plasmatic ratio confirms that KZn with relatively dense cytoplasms are immature cells of this specialised line, although they possess rer cisterns (Fig. 4A). In P. cultripes, the biosynthesis machinery includes Golgi stacks, releasing small vesicles with moderately opaque content (Fig. 4B). In the supranuclear cytoplasm, this product forms clusters of larger, translucent vesicles (up to $1.5 \mu \mathrm{m}$ in diameter, Fig. 4C) contiguous to opaque mucous granules in pavement cells (Fig. 4C). The mucous product displays similar, secretory phase-dependent features in the two species investigated: small (up to $0.5 \mu \mathrm{m}$ ), electron-dense granules during intracytoplasmic storage (Fig. 4C, E), and large (up to $2 \mu \mathrm{m}$ ), moderately opaque granules during release (Fig. 4C, D). Near the body surface, contiguous cells are joined together by serial desmosomes, so that the intercellular spaces are reduced to slender interstices (Fig. 4C-E). The cytoplasm of pavement cells is opaque (Fig. 4C), but with a centralperipheral density gradient (Fig. 4E) towards the skin surface (Fig. 4D). 


\section{Discussion}

Limbless tadpoles of Pelobates cultripes and Phyllobates bicolor possess KZn in the basal epidermal layer, namely ephemeral cells (Fröhlich et al. 1977), destined to be substituted by typical keratinocytes of the anuran epidermis. In the ontogenetic range observed, KZn show no degeneration features at all, and retain their proliferative potential, at least in intermediate stage of maturation. KZn can regulate the cytoplasm turgor by active transmembranary transport of ions (Fröhlich et al., 1978) and act as pressure-elasticity modules, recalling the notochordal cells in their mechanical properties (Fröhlich et al., 1977). However, the hydrostatic pressure requires a stiffness component to perform a supporting role: this is accomplished by the tonofilament bundles in the peripheral cytoskeleton. Tonofilaments form compact bands in P. bicolor $\mathrm{KZn}$, but in P. cultripes they are arranged in peculiar micro-trabeculatures, that foreshadow the Langerhans net of Leydig cells (Fährmann, 1971a, b; Greven, 1980; Rosenberg et al., 1982; Kantorek and Clemen, 1990). However, the LC peripheral filaments are assembled in a more solid arrangement, and in Salamandridae, the bundles form a regular network with polygonal meshes (Delfino and Malentacchi, 2006). The patterns of vesicle production described in $\mathrm{KZn}$ of $P$. cultripes represent further morpho-functional traits shared with Leydig cells, as suggested by similar features in the organelles involved (Rosenberg et al., 1982; Kantorek and Clemen, 1990). Homology between KZn and LCs is, nevertheless, a matter of debate, involving the three orders of extant amphibians with two possible contradictory meanings: Pflugfelder and Schubert (1965), and Nieuwkoop and Faber (1967) assign these cells to the same line. Fox (1988), on the contrary, maintains that Leydig cells have no homologous counterparts in Anura, while they are shared by urodele and Ichtyophis larvae. This suggests a relationship between Caudata and Gymnophiona which may be of phylogenetic significance (Fox, 1986b). In the light of the possible evolution by convergence of KZn and LCs, it is of interest that their typical ultrastructural traits: lucent cytoplasm and a peripheral felt-work of tonofilaments, have also been described in large epidermal cells of bony fishes (Whitear, 1986; Fox, 1989; Yokoya and Tamura, 1992). Possibly, the wide distribution of large clear cells among water-inhabiting vertebrates comes from their adaptive flexibility. Along with the mechanical function, these cells may regulate intraepidermal water flow (Fröhlich et al., 1977) and/or contrast dehydration (Kelly, 1966; Yokoya and Tamura, 1992).

\section{References}

Breckenridge WR, Nathanael S, Pereira L.1987. Some aspects of the biology and development of Ichthyophis glutinosus (Amphibia: Gymnophiona). Journal of Zoology. (London) 211: 437-449.

Delfino G. 1991. Ultrastructural aspects of venom secretion in anuran cutaneous glands. In: Tu AT, ed. Handbook of natural toxins: Reptile venoms and toxins. Vol. 5, Marcel Dekker Inc., New York: 777-802.

Delfino G, Brizzi R, Feri L. 1995b. Chemical skin defence in Bufo bufo: an ultrastructural study during ontogenesis. Zoologische Anzeiger 234: 101-111.

Delfino G, Brizzi R, Jantra S, Feri L. 1995a. Post-Golgian maturative processes during the biosynthesis of poison secretion in cutaneous glands of the European common toad Bufo bufo. Journal of Natural Toxins 4: 97-113.

Delfino G, Malentacchi C. 2006. Poison glands in anurans: an example of adaptative plasticity in the secretory serous cell line in low vertebrate epidermis. In: Zuffi MAL, ed., Atti del $V$ Congresso Nazionale. Societas Herpetologica Italica, Firenze University Press: 39-47.

Fährmann W. 1971a. Die Morphodynamik der Epidermis des Axolotls (Siredon mexicanum Shaw) unter dem Einfluss von exogen appliziertem Thyroxin. I. Die Epidermis des neotenen Axolotls. Zeitschrift für Mikroskopische Anatomische Forschung 83: 472-506.

Fährmann W. 1971b. Die Morphodynamik der Epidermis des Axolotls (Siredon mexicanum Shaw) unter dem Einfluss von exogen appliziertem Thyroxin. II. Die Epidermis während der Metamorphose. Zeitschrift für Mikroskopische Anatomische Forschung 83: 535-568.

Fox A. 1986a. The skin of the amphibia: Epidermis. In: BereiterHahn J, Matoltsy AC, Richards KS, eds. Biology of the integument: Vertebrates. Vol.2, Springer, Heidelberg: 78-108.

Fox A. 1986b. Early development of caecilian skin with special reference to the epidermis. Journal of Herpetology. 20: 154167.

Fox H. 1988. Riesenzellen, goblet cells, Leydig cells and large clear cells of Xenopus, in the amphibian larval epidermis: fine structure and a consideration of their homology. Journal of Submicroscopic Cytology and Pathology 20: 437-451.

Fox H. 1989. Tail skin of the dipnoan Neoceratodus larva: fine structure and differentiation. Journal of Zoology (London) 217: 213-226.

Fröhlich J, Aurin H, Kemnitz P. 1977. Zur epidermalen Kugelzelle von Krallenfroschlarven. Verhandlungen des Anatomischen Gesellschaft 71: 1171-1175.

Fröhlich J, Dietzman K, Aurin H. 1978. Zur Histochemie der epidermalen Kugelzelle von Krallenfroschlarven (Xenopus laevis Daudin). Acta histochemica 61: 155-161.

Frost DR, Grant T, Faivovich J, Bain RH, Haas A, Haddad CFB, De Sá RO, Channing A, Wilkinson M, Donnellan SC, Raxworthy CJ, Campbell JA, Blotto BI, Moler P, Drewes RC, Nussbaum RA, Lynch JD, Green DM, Wheeler WC. 2006. The amphibian tree of life. Bulletin of the America Museum of Natural History 297: 1-370. 
Gosner KL. 1960. A simplified table for staging anuran embryos and larvae with notes on identification. Herpetologica 16: 183-190.

Greven H. 1980. Ultrastructural investigation of the epidermis and the gill epithelium in the intrauterine larvae of Salamandra salamandra (L.) (Amphibia Urodela). Zeitschrift für Mikroskopische Anatomische Forschung 94: 196-208.

Jarial SM. 1989. Fine structure of epidermal Leydig cells in the axolotl Ambystoma mexicanum in relation to their function. Journal of Anatomy 167: 95-102.

Karnovsky MJ. 1965. A formaldehyde-glutaraldehyde fixative of high osmolarity for use in electron microscopy. Journal of Cell Biology 27: 137A.

Kantorek S, Clemen G. 1990. Das Oropharyngealepithel und seine Leydigschen Zellen beirn Adultus von Ambystoma mexicanum Shaw (Urodela Ambystomatidae). Acta Biologica Benrodis 2: 89-103.

Kelly DE. 1966. The Leydig cell in larval amphibian epidermis. Fine structure and function. Anatomical Record 154: 685700.

Nieuwkoop PD, Faber J. 1967. The development of the larval skin. In: Normal table of Xenopus laevis (Daudin) Second edition, North-Holland, Amsterdam, 41.

Pfeiffer W. 1974. Pheromones in fish and amphibia. In: Birch ME, ed. Pheromones. Elsevier/North-Holland, Amsterdam: 269-296.
Pflugfelder O, Shubert G. 1965. Elektronenmikroskopische Untersuchungen an der Haut von Larven-und Metamorphosestadien von Xenopus laevis nach Kaliumperchloratbehandlung. Z. Zellforschung und Mikroskopische Anatomi 67: 96112.

Quagliata S, Malentacchi C, Delfino C, Brunasso AMG, Delfino G. 2006. Adaptative evolution of secretory cell lines in vertebrate skin. Caryologia 59: 187-206.

Rosenberg M, Lewinson D, Warburg MR. 1982. Ultrastructural studies of the epidermal Leydig cell in larvae of Salamandra salamandra (Caudata, Salamandrida). Journal of Morphology 174: 275-281.

Seki T, Kikuyama S, Yanaihara N. 1989. Development of Xenopus laevis skin glands producing 5-hydroxytryptamine and caerulein. Cell Tissue Research 258: 483-489.

Whitear M. 1986. The skin of fishes including cyclostomes: Epidermis. In: Bereiter-Hahn J, Matoltsy AC, Richards KS, eds. Biology of the integument: Vertebrates. Vol. 2, Springer, Heidelberg: 8-38.

Yokoya S, Tamura OS. 1992. Fine structure of the skin of the amphibious fishes Boleophthalmus pectinirostris and Periophtalmus cantonensis, with special reference to the location of blood vessels. Journal of Morphology 214: 287-297.

Received: 17 May 2007

Accepted: 25 September 2007 